\title{
Laboratory photochemical processing of aqueous aerosols: formation and degradation of dicarboxylic acids, oxocarboxylic acids and $\alpha$-dicarbonyls
}

\author{
C. M. Pavuluri ${ }^{1}$, K. Kawamura ${ }^{1}$, N. Mihalopoulos ${ }^{1,2,3}$, and T. Swaminathan ${ }^{4}$ \\ ${ }^{1}$ Institute of Low Temperature Science, Hokkaido University, Sapporo 060-0819, Japan \\ ${ }^{2}$ Environmental Chemical Processes Laboratory, Department of Chemistry, University of Crete, \\ P.O. Box 2208, 71003 Voutes, Heraklion, Greece \\ ${ }^{3}$ Institute for Environmental Research and Sustainable Development, National Observatory of Athens, \\ 15236 Palea Penteli, Greece \\ ${ }^{4}$ Department of Chemical Engineering, Indian Institute of Technology Madras, Chennai 600036, India \\ Correspondence to: K. Kawamura (kawamura@lowtem.hokudai.ac.jp)
}

Received: 8 December 2014 - Published in Atmos. Chem. Phys. Discuss.: 15 January 2015

Revised: 27 June 2015 - Accepted: 1 July 2015 - Published: 20 July 2015

\begin{abstract}
To better understand the photochemical processing of dicarboxylic acids and related polar compounds, we conducted batch UV irradiation experiments on two types of aerosol samples collected from India, which represent anthropogenic (AA) and biogenic (BA) aerosols, for time periods of 0.5 to $120 \mathrm{~h}$. The irradiated samples were analyzed for molecular compositions of diacids, oxoacids and $\alpha$-dicarbonyls. The results show that photochemical degradation of oxalic $\left(\mathrm{C}_{2}\right)$, malonic $\left(\mathrm{C}_{3}\right)$ and other $\mathrm{C}_{8}-\mathrm{C}_{12}$ diacids overwhelmed their production in aqueous aerosols, whereas succinic acid $\left(\mathrm{C}_{4}\right)$ and $\mathrm{C}_{5}-\mathrm{C}_{7}$ diacids showed a significant increase (ca. 10 times) during the course of irradiation experiments. The photochemical formation of oxoacids and $\alpha$ dicarbonyls overwhelmed their degradation during the early stages of experiment except for $\omega$-oxooctanoic acid $\left(\omega \mathrm{C}_{8}\right)$, which showed a similar pattern to that of $\mathrm{C}_{4}$. We also found a gradual decrease in the relative abundance of $\mathrm{C}_{2}$ to total diacids and an increase in the relative abundance of $\mathrm{C}_{4}$ during prolonged experiment. Based on the changes in concentrations and mass ratios of selected species with the irradiation time, we hypothesize that iron-catalyzed photolysis of $\mathrm{C}_{2}$ and $\mathrm{C}_{3}$ diacids controls their concentrations in Fe-rich atmospheric waters, whereas photochemical formation of $\mathrm{C}_{4}$ diacid (via $\omega \mathrm{C}_{8}$ ) is enhanced with photochemical processing of aqueous aerosols in the atmosphere. This study demonstrates that the ambient aerosols contain abundant precursors
\end{abstract}

that produce diacids, oxoacids and $\alpha$-dicarbonyls, although some species such as oxalic acid decompose extensively during an early stage of photochemical processing.

\section{Introduction}

Dicarboxylic acids and related polar compounds constitute a significant fraction of water-soluble organic aerosols in the atmosphere (Saxena and Hildemann, 1996; Kawamura and Sakaguchi, 1999; Pavuluri et al., 2010). They have a potential contribution to the formation of cloud condensation nuclei due to their water-soluble and hygroscopic properties (Saxena and Hildemann, 1996; Giebl et al., 2002). Thus diacids and related compounds have an impact on the indirect radiative forcing and hydrological cycle (Twomey, 1977; Albrecht, 1989). They also involve in a series of reactions occurring in gas phase, aerosols and atmospheric waters (Chebbi and Carlier, 1996; Z. H. Wang et al., 2010). Although diacids, oxoacids and $\alpha$-dicarbonyls can be directly emitted into the atmosphere from incomplete combustion of fossil fuels (Kawamura and Kaplan, 1987) and biomass burning (Narukawa et al., 1999), they are mainly formed by secondary processes of volatile organic compounds of anthropogenic and biogenic origin (Kawamura et al., 1996a; Kawamura and Sakaguchi, 1999; Kanakidou et al., 2005). 
They are further subjected to photochemical oxidation during long-range transport; e.g., carbonyls to carboxylic acids (Tilgner and Herrmann, 2010) and breakdown of higher to lower diacids (Kawamura and Sakaguchi, 1999; Matsunaga et al., 1999; G. Wang et al., 2010).

Molecular distributions of diacids in atmospheric aerosols have generally been reported with a predominance of oxalic $\left(\mathrm{C}_{2}\right)$ acid followed by malonic $\left(\mathrm{C}_{3}\right)$ or succinic $\left(\mathrm{C}_{4}\right)$ acid in different environments (Kawamura and Kaplan, 1987; Kawamura and Ikushima, 1993; Kawamura and Sakaguchi, 1999; Narukawa et al., 1999; Pavuluri et al., 2010). The predominance of $\mathrm{C}_{2}$ in different environments is likely because it is an ultimate end product in the chain reactions of diacids and various precursors including aromatic hydrocarbons, isoprene, alkenes and $\alpha$-dicarbonyls (Kawamura et al., 1996a; Warneck, 2003; Ervens et al., 2004b; Lim et al., 2005; Carlton et al., 2007; Charbouillot et al., 2012). In contrast, $C_{4}$ was reported to be more abundant than $\mathrm{C}_{2}$ in some aerosol samples collected from Antarctica (Kawamura et al., 1996b), the Arctic (Kawamura et al., 2010) and over the Arctic Ocean (Kawamura et al., 2012) as well as in ice core samples from Greenland (Kawamura et al., 2001). In addition, a significant reduction in $\mathrm{C}_{2}$ diacid concentration and an inverse relationship between $\mathrm{C}_{2}$ and $\mathrm{Fe}$ has been reported in stratocumulus clouds over the northeastern Pacific Ocean (Sorooshian et al., 2013). The predominance of $C_{4}$ over $C_{2}$ in ice core samples and atmospheric aerosols from polar regions, particularly in the Arctic marine aerosol samples collected under overcast conditions with fog or haze events (Kawamura et al., 2012) and the reduction of $\mathrm{C}_{2}$ in cloud water, suggest that photochemical formation of $\mathrm{C}_{4}$ and/or degradation of $\mathrm{C}_{2}$ (Pavuluri and Kawamura, 2012) should be enhanced in atmospheric waters.

However, the photochemical formation and degradation of diacids and related compounds are not fully understood, particularly in aqueous phase because the composition of aqueous solutions used in laboratory experiments do not reflect the complex mixture of organic and inorganic aerosol constituents in the atmosphere and the experimental conditions are not necessarily atmospherically relevant (Ervens et al., 2011). Hence, it is required to investigate the fate of diacids and related polar compounds with photochemical processing in atmospheric waters. In this study, we conducted a laboratory experiment using two types of ambient aerosol samples collected from Chennai, India, which represent anthropogenic (AA) and biogenic (BA) aerosols. The samples were exposed to UV irradiation in the presence of moisture for different time ranging from 0.5 to $120 \mathrm{~h}$ and then analyzed for diacids, oxoacids and $\alpha$-dicarbonyls. Here, we report their molecular compositions and discuss the photochemical formation and/or degradation of diacids as a function of the irradiation time. Based on the results obtained, we propose possible photochemical formation and degradation pathways of diacids and related compounds with atmospheric implications.

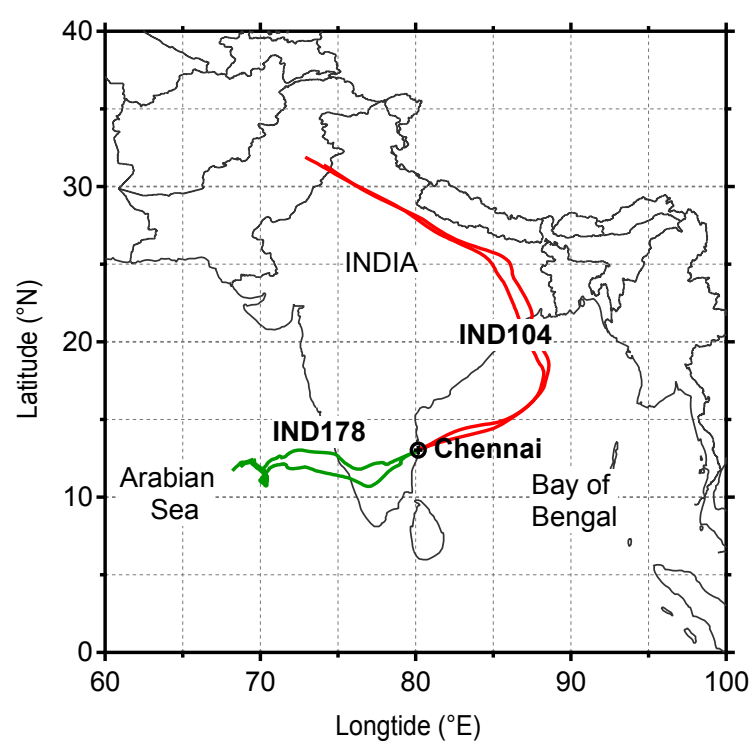

Figure 1. A map of South Asia with sampling site, Chennai $\left(13.04^{\circ} \mathrm{N}, 80.17^{\circ} \mathrm{E}\right)$, India, together with plots of 10 -day air mass trajectories arriving at $500 \mathrm{~m}$ a.g.l. over Chennai, India.

\section{Materials and methods}

\subsection{Atmospheric aerosol samples}

In this study, we used two types of atmospheric aerosol $\left(\mathrm{PM}_{10}\right)$ samples that were collected in winter on $28 \mathrm{Jan}-$ uary (IND104) and in summer on 25 May (IND178) 2007 during daytime (ca. 06:00-18:00 h local time) from Chennai $\left(13.03^{\circ} \mathrm{N}, 80.17^{\circ} \mathrm{E}\right)$, India, using a high volume air sampler and pre-combusted $\left(450^{\circ} \mathrm{C}, 4 \mathrm{~h}\right)$ quartz fiber filters. Sampling was conducted on the rooftop of the mechanical sciences building ( $\sim 18 \mathrm{~m}$ a.g.l., above the ground level) at the Indian Institute of Technology Madras (IITM) campus. The details of sampling site and meteorology are described elsewhere (Pavuluri et al., 2010). The sample filter was placed in a preheated glass jar with a Teflon-lined screw cap and stored in darkness at $-20^{\circ} \mathrm{C}$ prior to the experiment. Figure 1 presents 10-day backward air mass trajectories arriving in Chennai at $500 \mathrm{~m}$ a.g.l. for every $6 \mathrm{~h}$ during the sampling periods of IND104 and IND178. Table 1 shows concentrations of elemental carbon (EC), organic carbon (OC), levoglucosan and sums of hopanes (specific biomarkers of petroleum and coal) and lipid class compounds (fatty acids and fatty alcohols) in IND104 and IND178 (Fu et al., 2010; Pavuluri et al., 2011).

The air mass trajectories showed that the air masses for the IND104 sample originated from the north Indian subcontinent passing over the Bay of Bengal (Fig. 1). In North India, anthropogenic emissions are mainly derived from fossil fuel combustion and forest fires (Lelieveld et al., 2001; Reddy and Venkataraman, 2002a). This sample is enriched with EC (Table 1). The anthropogenic signature of IND104 is further 
Table 1. Concentrations of carbonaceous components, organic molecular tracer compounds, diacids and related compounds, trace elements, metals and water-soluble iron species in non-irradiated IND104 (anthropogenic aerosols: AA) and IND178 (biogenic aerosols: BA) aerosol samples collected from Chennai, India.

\begin{tabular}{|c|c|c|}
\hline & \multicolumn{2}{|c|}{ Concentrations $\left(\mathrm{ng} \mathrm{m}^{-3}\right.$ ) } \\
\hline & IND104 (AA) & IND178 (BA) \\
\hline Organic carbon $^{\mathrm{a}}$ & 6400 & 9820 \\
\hline Elemental carbon $^{\mathrm{a}}$ & 4810 & 1810 \\
\hline Levoglucosan ${ }^{b}$ & 79.1 & 158 \\
\hline Hopanes $\left(\mathrm{C}_{27}-\mathrm{C}_{35}\right)^{\mathrm{b}}$ & 11.8 & 3.9 \\
\hline Fatty acids $\left(\mathrm{C}_{8}-\mathrm{C}_{34}\right)^{\mathrm{b}}$ & 167 & 297 \\
\hline Fatty alcohols $\left(\mathrm{C}_{14}-\mathrm{C}_{34}\right)^{\mathrm{b}}$ & 93.3 & 178 \\
\hline Total diacids & 1030 & 640 \\
\hline Total oxoacids & 110 & 62.2 \\
\hline Total $\alpha$-dicarbonyls & 10.9 & 11.6 \\
\hline $\mathrm{Al}$ & 15100 & 914 \\
\hline $\mathrm{Ca}$ & 1640 & 0.00 \\
\hline $\mathrm{Cd}$ & 10.7 & 1.73 \\
\hline $\mathrm{Co}$ & 1.07 & 0.00 \\
\hline $\mathrm{Cr}$ & 5.33 & 0.00 \\
\hline $\mathrm{Cu}$ & 796 & 13.9 \\
\hline $\mathrm{Fe}$ & 2070 & 553 \\
\hline $\mathrm{K}$ & 1220 & 893 \\
\hline $\mathrm{Mg}$ & 679 & 90.2 \\
\hline $\mathrm{Mn}$ & 129 & 19.1 \\
\hline $\mathrm{Na}$ & 1890 & 408 \\
\hline $\mathrm{Ni}$ & 58.7 & 106 \\
\hline $\mathrm{P}$ & 62.9 & 0.00 \\
\hline $\mathrm{Pb}$ & 133 & 39.9 \\
\hline$S$ & 4640 & 5820 \\
\hline $\mathrm{Sb}$ & 13.9 & 29.5 \\
\hline $\mathrm{V}$ & 9.60 & 0.00 \\
\hline $\mathrm{Zn}$ & 2030 & 137 \\
\hline $\mathrm{Fe}_{\mathrm{WS}}^{\mathrm{c}}$ & 57.0 & 78.3 \\
\hline $\mathrm{Fe}^{2+}$ & 20.5 & 30.0 \\
\hline $\mathrm{Fe}^{3+}$ & 36.6 & 48.4 \\
\hline
\end{tabular}

${ }^{a}$ Data are obtained from Pavuluri et al. (2011); ${ }^{\text {b }}$ data are obtained from Fu et al. (2010); ${ }^{\mathrm{c}} \mathrm{Fe}$ WS is water-soluble Fe.

supported by high abundances of hopanes. In contrast, the air masses for the IND178 sample originated from the Arabian Sea passing over the south Indian subcontinent (Fig. 1), where the emissions from marine biota, combustion of biofuels (e.g., cow dung) (Reddy and Venkataraman, 2002b) and livestock (Garg et al., 2001) are important. In addition, emission of volatile organic compounds (VOCs) from tropical plant species in India is enhanced in summer (Padhy and Varshney, 2005). This sample is enriched with OC but EC is less abundant (Table 1). The biogenic signature of IND178 is supported by high abundances of fatty acids and fatty alcohols (Table 1). Hence, we conclude that IND104 represents AA whereas IND178 represents BA.

\subsection{Determination of trace elements, metals and water-soluble iron species}

Trace elements and metals were determined using an inductively coupled plasma mass spectrometry (Thermo Electron $\mathrm{X}$ Series) after the acid microwave digestion of samples (a filter disc of $1.8 \mathrm{~cm}$ in diameter) as reported by Theodosi et al. (2010b). Recoveries obtained with the use of certified reference materials ranged from 90.0 to $104.1 \%$. Watersoluble iron ( $\mathrm{Fe}_{\mathrm{WS}}$ : sum of $\mathrm{Fe}^{2+}$ and $\mathrm{Fe}^{3+}$ species) was determined spectrometrically using the ferrozine colorimetric method developed by Stookey (1970) as reported by Theodosi et al. (2010a). $\mathrm{Fe}^{2+}$ was measured using the same procedure without adding the reducing agent (hydroxylamine hydrochloride), and then $\mathrm{Fe}^{3+}$ was estimated indirectly as the difference between $\mathrm{Fe}_{\mathrm{Ws}}$ and $\mathrm{Fe}^{2+}$. The recovery was $\sim 98.3 \%$ for both $\mathrm{Fe}_{\mathrm{WS}}$ and $\mathrm{Fe}^{2+}$.

\subsection{Irradiation experiment of aerosol samples}

Batch UV irradiation experiments using two aerosol samples (AA and BA) were conducted separately for $0.5,1.5$, $3.0,6.0,12,18,24,36,48,72,96$ and $120 \mathrm{~h}$, because both primary and secondary chemical species associated with aerosols can be subjected to significant photochemical processing throughout their stay (i.e., up to 12 days) in the atmosphere (Warneck, 2003). In each experiment, $\sim 12 \mathrm{~cm}^{2}$ (ca. $3 \times 4 \mathrm{~cm}$ ) of sample filter was cut into $3 \sim 4$ pieces and placed vertically in a cleaned quartz reaction vessel (cylinder, $100 \mathrm{~mL}$ ) with the sample surface facing to UV light as depicted in Fig. 2. The sample was fully wetted by injecting $\sim 0.4 \mathrm{~mL}$ of ultra pure organic free Milli-Q water and sealed with Teflon-lined screw cap under the ambient pressure. Furthermore, the available excess Milli-Q water (Fig. 2) may promote humid $(\mathrm{RH}=100 \%)$ environment in the reaction vessel by equilibrium between water vapor and Milli-Q water. The aqueous ambient aerosol sample was then irradiated with a low-pressure mercury lamp (Ushio, UL0-6DQ) that emits a UV whose spectra are characterized by a main peak at $254 \mathrm{~nm}$ and minor peak at $185 \mathrm{~nm}$ as well as a broad peak at $>254 \mathrm{~nm}$. The experimental setup (Fig. 2) was covered with a cardboard box containing a hole on each side for the passage of ambient air and placed in a draft chamber. The temperature around the experimental system (i.e., inside cardboard box) was equivalent to room temperature $\left(25 \pm 1^{\circ} \mathrm{C}\right)$.

The main objective of UV irradiation with a wavelength primarily at $254 \mathrm{~nm}$, rather than a solar spectrum, was to produce significant amounts of hydroxyl radicals $\left(\mathrm{HO}^{\bullet}\right)$ from various sources (described below), which should be sufficient enough to act as the main oxidant in our experimental system. Although we do not preclude a minor photolysis of some organic compounds present in the aerosol samples by irradiation at $\leq 254 \mathrm{~nm}$, it is well established that low molecular weight diacids, oxoacids and $\alpha$-dicarbonyls 


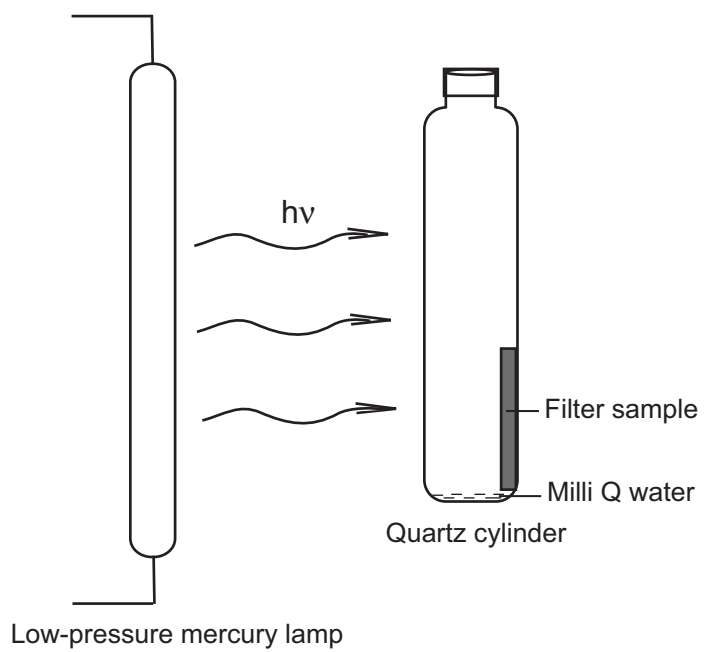

Figure 2. Schematic of experimental setup for irradiation of atmospheric aerosol filter sample.

including pyruvic acid and methylglyoxal have negligible absorbance at $254 \mathrm{~nm}$ and exhibit minimal photolysis, particularly when $\mathrm{HO}^{\bullet}$ reactions of organics are significant (Carlton et al., 2006; Yang et al., 2008b; Tan et al., 2012). Because sulfate is abundant in non-irradiated AA and BA (Pavuluri et al., 2011), the production of organosulfates could be significant upon irradiation (Noziere et al., 2010) in both the samples. However, the sulfate contents may not have a significant impact on the production rate of diacids and related compounds (Tan et al., 2009).

Furthermore, the photolysis of organics by the radiation of $185 \mathrm{~nm}$, the intensity of which is 100 times lower than that of $254 \mathrm{~nm}$, should be insignificant during the experiment because the $185 \mathrm{~nm}$ light intensity is small and is mostly absorbed by water due to its high absorption coefficient $\left(1.8 \mathrm{~cm}^{-1}\right.$ at $25^{\circ} \mathrm{C}$ ) (Weeks et al., 1963). It is well established that the photolysis rates of organics by the radiation of $185 \mathrm{~nm}$ are elevated only in the absence of dissolved oxygen (Shirayama et al., 2001); however, in aerated solutions under irradiation of $185 \mathrm{~nm}$, mainly water undergoes photolysis and produces the hydrogen atoms, which are scavenged by oxygen to form $\mathrm{HO}_{2}^{\bullet}$ radicals that are finally converted to $\mathrm{HO}^{\bullet}$ (Chitose et al., 2003; Yang et al., 2008b). Thus, the minor $185 \mathrm{~nm}$ light emitted from the UV source promotes the production of $\mathrm{HO}^{\bullet}$ during the experiment rather than the photolysis of the compounds of interest in this study. On the contrary, iron-dicarboxylate complexes (e.g., oxalate and malonate) can photolyze by absorbing both UV-C $(254 \mathrm{~nm})$ and UV-A light and their photolysis rate depends on the concentration of $\mathrm{Fe}$ in the given sample rather than the UV light wavelength (Zuo and Hoigne, 1994; Z. H. Wang et al., 2010; Pavuluri and Kawamura, 2012). In addition, radiation at $254 \mathrm{~nm}$ has been reported to impose only a marginal pho- tolysis of most of the inorganic species except for nitrate, which is one of the $\mathrm{HO}^{\bullet}$ sources (Yang et al., 2008b).

The irradiation of wetted aerosol sample at $254 \mathrm{~nm}$ induces the formation of $\mathrm{O}_{3}$ from the dissolved $\mathrm{O}_{2}$, followed by the generation of $\mathrm{H}_{2} \mathrm{O}_{2}$; the photolysis of $\mathrm{H}_{2} \mathrm{O}, \mathrm{NO}_{3}^{-}$, $\mathrm{NO}_{2}^{-}, \mathrm{H}_{2} \mathrm{O}_{2}, \mathrm{Fe}(\mathrm{OH})^{2+}$ and certain organic compounds; and Fenton's reaction of photochemically formed $\mathrm{Fe}^{2+}$ and $\mathrm{H}_{2} \mathrm{O}_{2}$ to produce $\mathrm{HO}^{\bullet}$ in aqueous phase (Arakaki and Faust, 1998; Carlton et al., 2006; Yang et al., 2008b). In fact, a large amount of $\mathrm{Fe}$, including water-soluble $\mathrm{Fe}^{2+}$ and $\mathrm{Fe}^{3+}$ species, is available in both AA and BA samples (Table 1), which could promote the Fenton's reaction upon UV irradiation. In addition, $\mathrm{O}_{3}, \mathrm{H}_{2} \mathrm{O}_{2}, \mathrm{HOO}^{\bullet}$ and $\mathrm{NO}_{2}$ formed in aqueous phase reactions may be partitioned into gas phase and generate the gaseous $\mathrm{HO}^{\bullet}$ that should be re-partitioned into aqueous phase (Arakaki and Faust, 1998). These sources of $\mathrm{HO}^{\bullet}$ are similar to those of atmospheric waters: (i) gas/drop partitioning of $\mathrm{HO}^{\bullet}$ and (ii) gas/drop partitioning of $\mathrm{O}_{3}$ followed by a reaction with peroxy radical $\left(\mathrm{HOO}^{\bullet}\right)$; (iii) photolysis of $\mathrm{H}_{2} \mathrm{O}, \mathrm{NO}_{3}^{-}, \mathrm{NO}_{2}^{-}, \mathrm{H}_{2} \mathrm{O}_{2}, \mathrm{Fe}(\mathrm{OH})^{2+}$ and certain organic compounds; and (iv) Fenton's reaction of $\mathrm{Fe}^{2+}$ and $\mathrm{H}_{2} \mathrm{O}_{2}$ (Arakaki and Faust, 1998).

Unfortunately, we could not approximate the actual concentrations of $\mathrm{HO}^{\bullet}$ in our experiments because we did not add any chemical (e.g., a standard compound whose kinetics are known) in order to keep our experimental system as realistic as possible. Furthermore, the formation of $\mathrm{O}_{3}$ from the initially available $\mathrm{O}_{2}(\sim 0.94 \mathrm{mM})$ in the reaction vessel may not cause the deficit of the $\mathrm{O}_{2}$ that could potentially induce the polymerization of organics during the irradiation on aerosols for several hours, because the additional $\mathrm{O}_{2}$ could be produced from the gaseous $\mathrm{HOO}^{\bullet}$ formed by photolysis of organics and Fenton's reaction (Arakaki and Faust, 1998) during the experiment.

\subsection{Measurements of diacids, oxoacids and $\alpha$-dicarbonyls}

Immediately after the irradiation, samples were analyzed for diacids, oxoacids and $\alpha$-dicarbonyls using a method reported elsewhere (Kawamura, 1993; Kawamura and Ikushima, 1993). Briefly, the irradiated sample filter was extracted with Milli-Q water $(10 \mathrm{~mL} \times 3)$ under ultra sonication for $10 \mathrm{~min}$ and the extracts were concentrated to near dryness using a rotary evaporator under vacuum. The extracts were then derivatized with $14 \% \mathrm{BF}_{3} / \mathrm{n}$-butanol at $100^{\circ} \mathrm{C}$ to butyl esters and/or butoxy acetals. Both the esters and acetals were extracted with $n$-hexane and then determined using a capillary gas chromatograph (HP 6890) and gas chromatographymass spectrometer (Thermo Trace MS). Recoveries of authentic standards spiked to a pre-combusted quartz fiber filter were $73 \%$ for oxalic $\left(\mathrm{C}_{2}\right)$ acid and more than $84 \%$ for malonic $\left(\mathrm{C}_{3}\right)$, succinic $\left(\mathrm{C}_{4}\right)$ and adipic $\left(\mathrm{C}_{6}\right)$ acids (Pavuluri et al., 2010). The analytical errors in duplicate analysis of the aerosol filter sample are within $9 \%$ for major species. 
Gas chromatogram of the field and laboratory blanks showed small peaks for $\mathrm{C}_{2}$, phthalic $(\mathrm{Ph})$ and glyoxylic acids. Concentrations of all the species reported here are corrected for the non-irradiated field blanks (Pavuluri et al., 2010).

\subsection{Quality control}

To examine the possible experimental errors, including the distribution of organic/inorganic constituents over the filter sample, we conducted replicate experiments $(n=3)$ for $18 \mathrm{~h}$ irradiation of the AA sample by using the sample cut taken from different parts of the filter sample for each experiment, because a deviation in the results of the irradiation experiment should become large if the impact of potential variance in chemical composition of aerosol at different parts of the single filter, size of the filter sample used (i.e., number of aerosols) and the amount of Milli-Q water added is significant. The experimental errors, including the analytical errors, were found to be within $11 \%$ for major species except for $\mathrm{C}_{3}$ diacid (19\%). These results suggest that organic and inorganic constituents are well distributed over the filter sample and took up water evenly distributed upon wetting. In addition, two irradiation experiments were conducted to check the procedural blank by using a clean quartz filter for 1.5 and $6.0 \mathrm{~h}$. No peaks were detected except for a small peak for $\mathrm{C}_{2}$ and $\mathrm{Ph}$. These results indicate that the occurrence of bias during the experiment is insignificant.

\section{Results and discussion}

\subsection{Concentrations of trace elements, metals and water-soluble iron species}

Concentrations of trace elements, metals and water-soluble Fe species $\left(\mathrm{Fe}^{2+}\right.$ and $\left.\mathrm{Fe}^{3+}\right)$ determined in non-irradiated AA and BA samples are presented in Table 1. The trace elements and metals in the AA sample, which mainly originate from soil dust (e.g., $\mathrm{P}, \mathrm{Al}, \mathrm{Ca}$ and $\mathrm{Fe}$ ), non-ferrous metallurgical industrial activities ( $\mathrm{Cd}, \mathrm{Cu}$ and $\mathrm{Zn}$ ) and fossil fuel combustion ( $\mathrm{Cr}, \mathrm{Pb}$ and $\mathrm{V}$ ) (Pacyna and Pacyna, 2001; Mahowald et al., 2008), are significantly more abundant than in BA (by up to several times higher) with the exception of $\mathrm{S}, \mathrm{Ni}$ and $\mathrm{Sb}$ (Table 1). The high abundances of trace metals in AA further suggest that the AA sample should contain high abundances of anthropogenic organic matter. The higher abundances of $\mathrm{S}, \mathrm{Ni}$ and $\mathrm{Sb}$ in BA than in AA may be due to high emissions of $\mathrm{S}$ from intensive consumption of biofuels, particularly cow dung that contains higher S content (Reddy and Venkataraman, 2002b), while $\mathrm{Ni}$ and $\mathrm{Sb}$ are from some specific industrial activities in southern India. Although watersoluble $\mathrm{Fe}^{2+}$ and $\mathrm{Fe}^{3+}$ species are abundant in both AA and $\mathrm{BA}$, their concentrations in BA are $30-50 \%$ higher than in AA (Table 1). Furthermore, the fraction of water-soluble Fe (Fews: sum of $\mathrm{Fe}^{2+}$ and $\mathrm{Fe}^{3+}$ ) in total particulate $\mathrm{Fe}\left(\mathrm{Fe}_{\mathrm{Tot}}\right)$ is $2.77 \%$ in $\mathrm{AA}$, whereas it is $14.6 \%$ in BA.

\subsection{Molecular compositions of diacids, oxoacids and $\alpha$-dicarbonyls}

A homologous series of normal $\left(\mathrm{C}_{2}-\mathrm{C}_{12}\right)$ and branched chain (iso- $\mathrm{C}_{4}-\mathrm{C}_{6}$ ) saturated $\alpha, \omega$-diacids were detected in both non-irradiated and irradiated AA and BA samples as well as aliphatic unsaturated diacids such as maleic (M), fumaric $(\mathrm{F})$ and methylmaleic $(\mathrm{mM})$ acids and aromatic diacids such as phthalic $(\mathrm{Ph})$, isophthalic $(i-\mathrm{Ph})$ and terephthalic $(t-\mathrm{Ph})$ acids. Diacids with an additional functional group, i.e., malic (hydroxysuccinic, $\left.\mathrm{hC}_{4}\right)$, ketomalonic $\left(\mathrm{kC}_{3}\right)$ and 4-ketopimelic $\left(\mathrm{kC}_{7}\right)$ acids, were detected together with $\omega$ oxoacids $\left(\omega \mathrm{C}_{2}-\omega \mathrm{C}_{9}\right)$, pyruvic acid (Pyr) and $\alpha$-dicarbonyls, i.e., glyoxal (Gly) and methylglyoxal (MeGly). $\omega \mathrm{C}_{6}$ will not be reported here due to the overlapping peak on the gas chromatograph.

Oxalic $\left(\mathrm{C}_{2}\right)$ acid was found to be the most abundant diacid in non-irradiated samples (accounting for $54 \%$ of total diacids in $\mathrm{AA}$ and $53 \%$ in $\mathrm{BA})$, followed by $\mathrm{Ph}(10 \%)$, $\mathrm{C}_{4}(9 \%), \mathrm{C}_{3}(8 \%)$ and $\mathrm{C}_{9}(4 \%)$ in $\mathrm{AA}$ and by malonic $\left(\mathrm{C}_{3}\right)(9 \%), \mathrm{C}_{4}(6 \%)$ and $t-\mathrm{Ph}(6 \%)$ acids in BA. Branched chain diacids were significantly lower than the corresponding normal structures in both samples. Glyoxylic $\left(\omega \mathrm{C}_{2}\right)$ acid is the most abundant oxoacid, comprising 64 and $57 \%$ of total oxoacids in AA and BA, respectively, followed by $\mathrm{Pyr}$ $(13 \%)$ and 4-oxobutanoic $\left(\omega \mathrm{C}_{4}\right)$ acid $(10 \%)$ in $\mathrm{AA}$ and $\omega \mathrm{C}_{4}$ $(18 \%)$ and Pyr (13\%) in BA. MeGly is more abundant than Gly in AA, whereas their abundances are equivalent in BA.

\subsection{Changes in concentrations of diacids and related compounds as a function of UV irradiation time}

Changes in concentrations of individual and total diacids as a function of UV irradiation time in AA and BA are depicted in Fig. 3, while those of oxoacids and $\alpha$-dicarbonyls as well as total oxoacids and $\alpha$-dicarbonyls in Fig. 4. Concentrations of $\mathrm{C}_{2}$ diacid were sharply decreased by a factor of 3-9 (from 553 to $61.7 \mathrm{ng} \mathrm{m}^{-3}$ in AA and from 339 to $118 \mathrm{ng} \mathrm{m}^{-3}$ in BA) within $6 \mathrm{~h}$ and $12 \mathrm{~h}$ of UV irradiation, respectively (Fig. 3a). Then the concentrations started to increase to maximize at $24 \mathrm{~h}\left(292 \mathrm{ng} \mathrm{m}^{-3}\right)$ in AA and $18 \mathrm{~h}\left(306 \mathrm{ng} \mathrm{m}^{-3}\right)$ in BA on further irradiation. They gradually decreased toward the end $(120 \mathrm{~h})$ of the experiment (Fig. 3a). Interestingly, $\mathrm{C}_{3}$ diacid showed a temporal variation similar to $\mathrm{C}_{2}$ in both $\mathrm{AA}$ and BA, except for a few points (Fig. 3b). Relative abundances of $\mathrm{C}_{2}$ in total diacids gradually decreased from nonirradiated samples (54\% in AA and $53 \%$ in BA) toward the end $(120 \mathrm{~h})$ of the experiment $(3.2 \%$ in AA and $9.2 \%$ in BA, Fig. 5).

Concentrations of $\omega \mathrm{C}_{2}$, an immediate precursor of $\mathrm{C}_{2}$ (Kawamura et al., 1996a; Warneck, 2003; Lim et al., 2005), increased with irradiation time up to $18 \mathrm{~h}$ in both AA and BA, except for two cases ( 3 and $6 \mathrm{~h}$ ) of AA, and then gradually decreased until the end $(120 \mathrm{~h})$ of the experiment, except for one case (36h) in AA (Fig. 4a). Pyr, Gly and MeGly, 

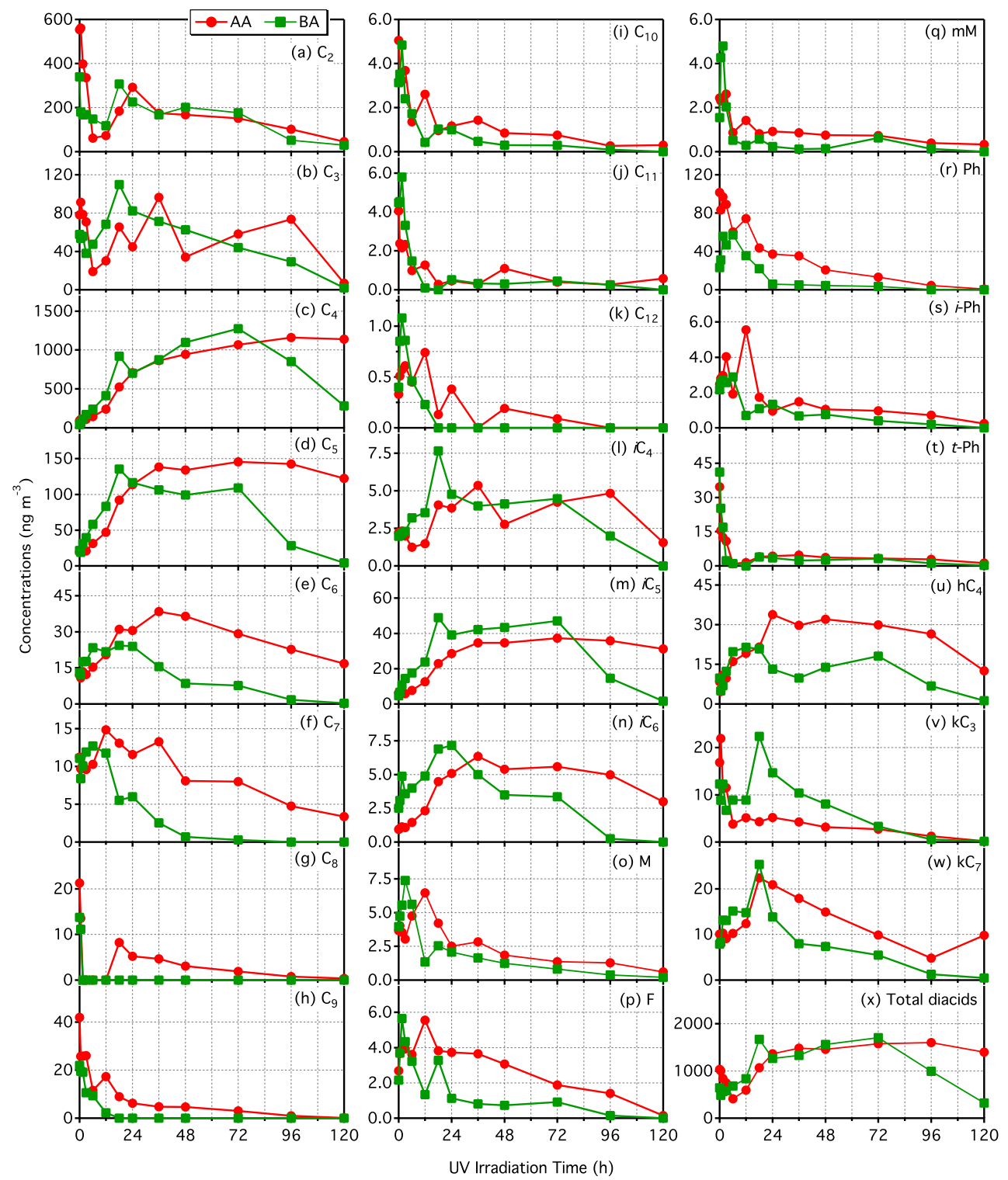

Figure 3. Changes in concentrations of individual dicarboxylic acids and total diacids as a function of UV irradiation time in anthropogenic (AA) and biogenic aerosols (BA).

which are the precursors of $\omega \mathrm{C}_{2}$ acid, are all produced by the oxidation of VOCs of anthropogenic and biogenic origin (Warneck, 2003; Ervens et al., 2004b; Lim et al., 2005; Carlton et al., 2006). They also increased with irradiation time up to $18-24 \mathrm{~h}$ in both samples and then gradually decreased (except for MeGly in AA) until the end $(120 \mathrm{~h})$ of the experiment (Fig. 4g, i, j). However, the other precursor of $\mathrm{C}_{2}$ diacid, $\mathrm{kC}_{3}$ diacid (Kawamura et al., 1996a), showed a decrease with irradiation time throughout the experiment except for in a few cases (Fig. 3v), whereas $\mathrm{hC}_{4}$, a precursor of $\mathrm{C}_{3}$ diacid (Kawamura et al., 1996a), increased up to $18 \mathrm{~h}$ in $\mathrm{BA}$ and $24 \mathrm{~h}$ in AA, remained relatively high until $72 \mathrm{~h}$ and then gradually decreased until the end $(120 \mathrm{~h})$ of the experiment (Fig. 3u).

In contrast, concentrations of $\mathrm{C}_{4}$ diacid showed a gradual increase with irradiation time up to $72 \mathrm{~h}$ in BA and $96 \mathrm{~h}$ in AA followed by a slight decrease in the AA and a sharp decrease in BA (Fig. 3c). Relative abundance of $\mathrm{C}_{4}$ diacid in total diacids also increased from $8.9 \%$ (non-irradiated) to $82 \%(120 \mathrm{~h}$ ) in AA and from 6.4 to $88 \%$ in BA (Fig. 5). Similarly, $\mathrm{C}_{5}$ diacid in AA (Fig. 3d) showed a gradual increase with irradiation up to $36 \mathrm{~h}$ and stayed almost constant until $96 \mathrm{~h}$ followed by a slight decrease. Similar trend was found in BA (Fig. 3d). Both $\mathrm{C}_{6}$ and $\mathrm{C}_{7}$ diacids showed an increase with irradiation up to $6-36 \mathrm{~h}$ and then a gradual decrease un- 

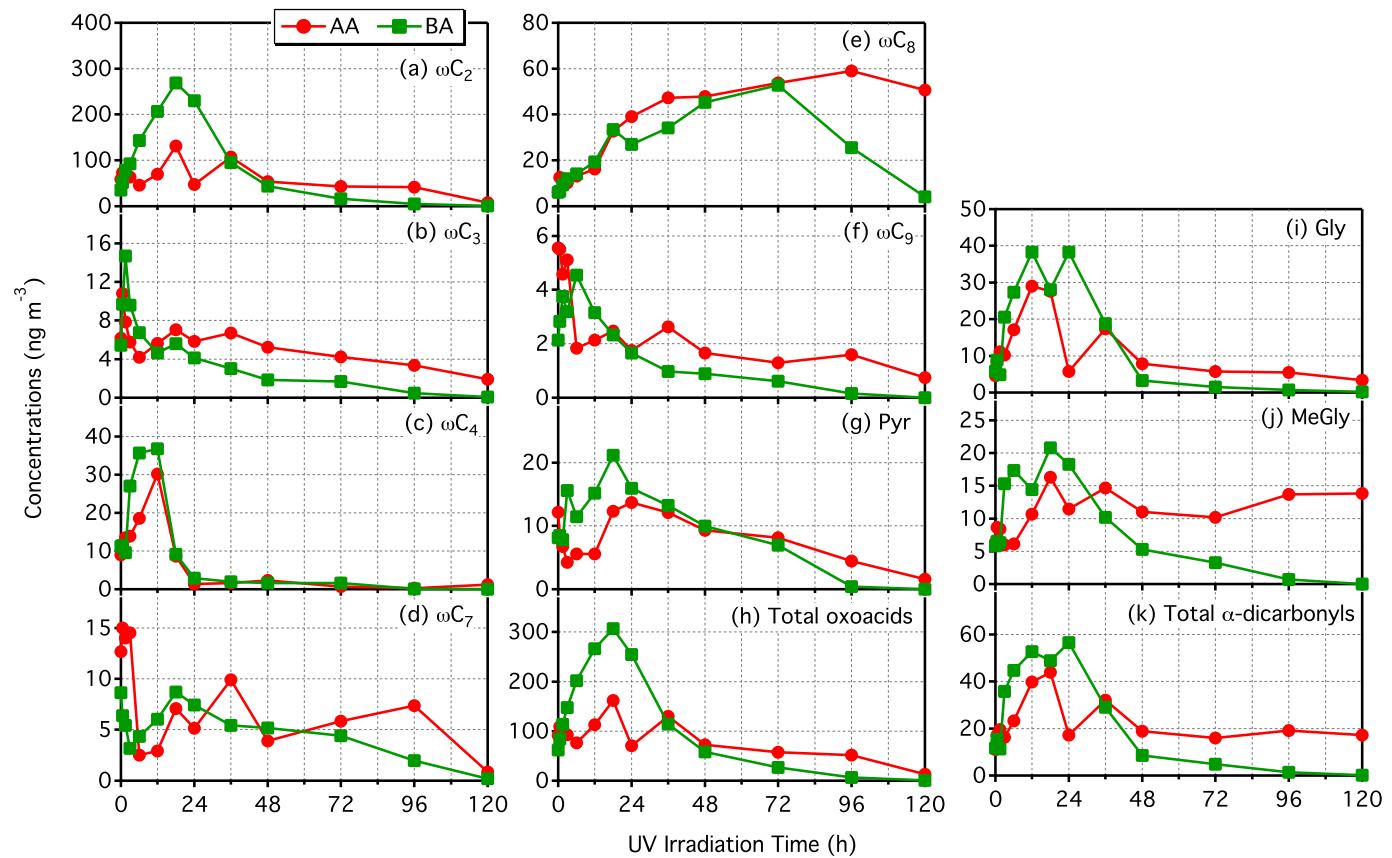

Figure 4. Changes in concentrations of individual oxoacids and $\alpha$-dicarbonyls and total oxoacids and $\alpha$-dicarbonyls as a function of UV irradiation time in AA and BA.
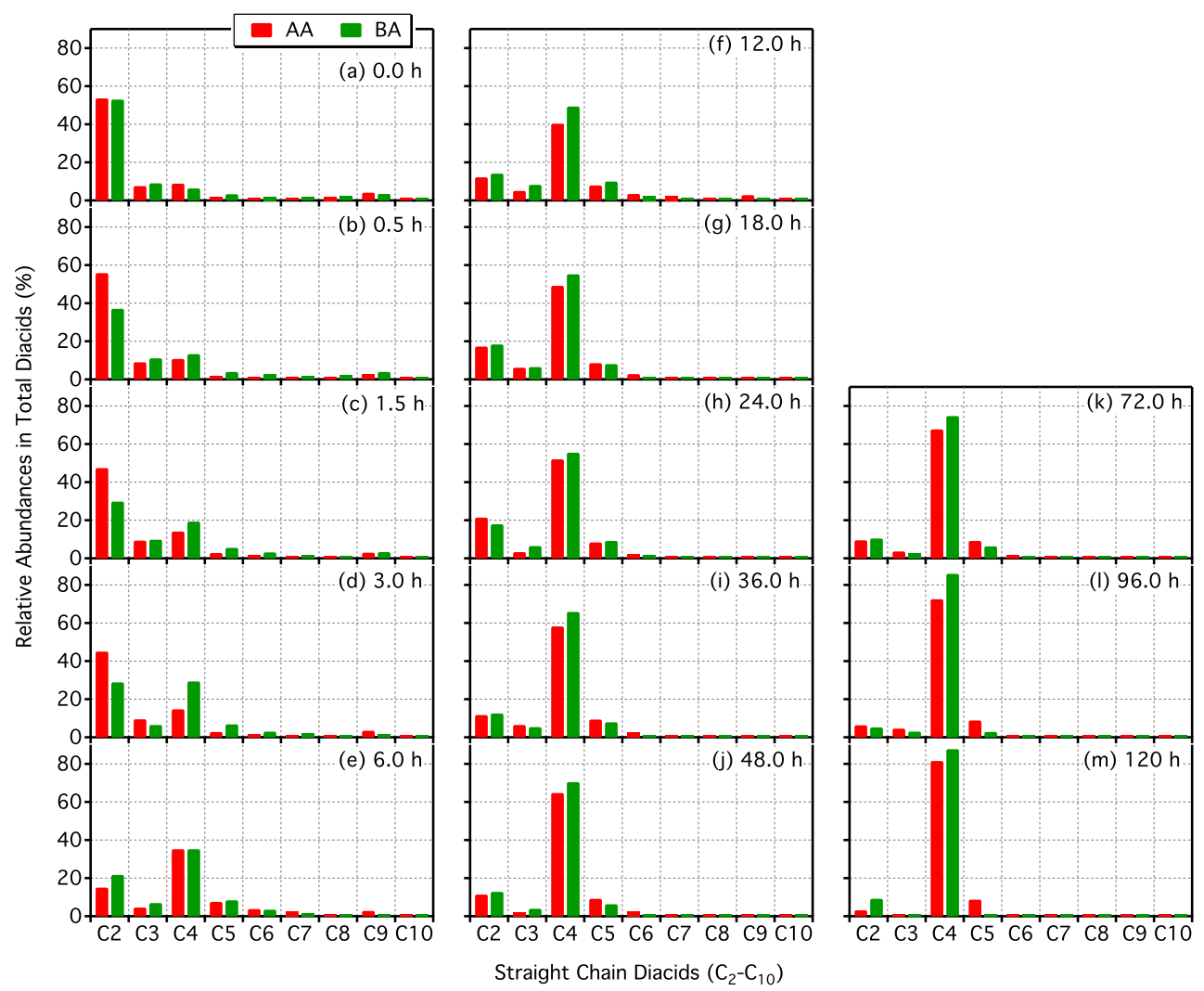

Figure 5. Changes in relative abundances of straight-chain diacids $\left(\mathrm{C}_{2}-\mathrm{C}_{10}\right)$ to total diacids as a function of UV irradiation time in $A A$ and BA. 

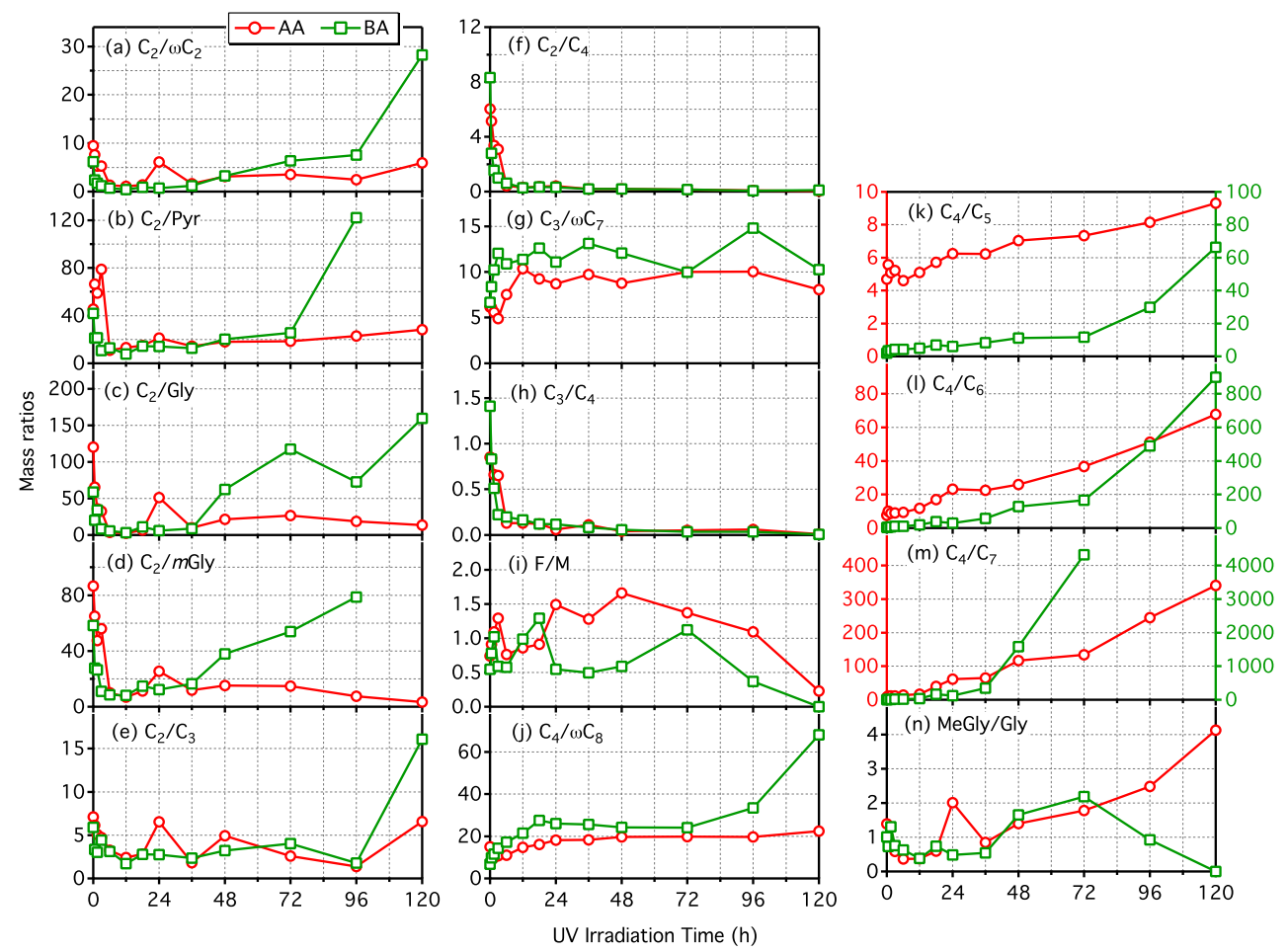

Figure 6. Changes in mass ratios of selected diacids, oxoacids and $\alpha$-dicarbonyls as a function of UV irradiation time in AA and BA.

til the end $(120 \mathrm{~h})$ of the experiment (Fig. 3e, f). Concentrations of $i \mathrm{C}_{4}$ diacid also increased with irradiation up to $18 \mathrm{~h}$ in $\mathrm{BA}$ and $36 \mathrm{~h}$ in $\mathrm{AA}$ and stayed relatively constant until 72 or $96 \mathrm{~h}$. Then, the concentrations gradually decreased until the end $(120 \mathrm{~h})$ of the experiment (Fig. 31$). i \mathrm{C}_{5}$ and $i \mathrm{C}_{6}$ diacids (Fig. $3 \mathrm{~m}, \mathrm{n}$ ) showed a very similar trend with their corresponding normal diacids (Fig. 3d, e).

Long-chain $\left(\mathrm{C}_{8}-\mathrm{C}_{12}\right)$ diacids showed a sharp decrease with irradiation up to $12 \mathrm{~h}$ and then a gradual decrease until the end $(120 \mathrm{~h}$ ) of the experiment (Fig. $3 \mathrm{~g}-\mathrm{k}) . \mathrm{C}_{8}, \mathrm{C}_{9}$ and $\mathrm{C}_{12}$ diacids fell below the detection limit within several hours, particularly in BA. Unsaturated aliphatic (M, F, mM and $\mathrm{Ph})$ and aromatic diacids $(i-\mathrm{Ph}$ and $t-\mathrm{Ph})$ showed a gradual decrease with irradiation except for a few cases during the early stages of the experiment (Fig. 3o-t). Concentrations of $\mathrm{kC}_{7}$ increased with irradiation time up to $18 \mathrm{~h}$ and then decreased gradually until $120 \mathrm{~h}$ (Fig. $3 \mathrm{w}$ ) whereas oxoacids, i.e., $\omega \mathrm{C}_{3}$, $\omega \mathrm{C}_{7}$ and $\omega \mathrm{C}_{9}$ acids, showed a gradual decrease with irradiation except for in a few cases (Fig. $4 b, d, f)$. However, $\omega \mathrm{C}_{4}$ acid showed a sharp increase up to $12 \mathrm{~h}$ and then a sharp decrease toward $24 \mathrm{~h}$ (Fig. 4c). Interestingly, the temporal pattern of $\omega \mathrm{C}_{8}$ acid (Fig. $4 \mathrm{e}$ ) was similar to that of $\mathrm{C}_{4}$ diacid (Fig. 3c).

Thus the changes in the concentrations of individual diacids, oxoacids and $\alpha$-dicarbonyls as well as relative abundances of individual diacids in total diacids and mass ratios of selected species in AA and BA were similar (Figs. 3-6), although significant differences are recognized between AA and BA samples during irradiation. Such similarities in the temporal variations of diacids and related polar compounds infer that their photochemical formation and degradation pathways in aqueous aerosols (Fig. 7) are almost same between anthropogenic and biogenic aerosols. However, there were significant differences in the rate of formation and/or degradation of diacids and related compounds between AA and BA, which might have been driven by the differences in the abundances of the diacids and related compounds as well as their precursor compounds in the original (non-irradiated) $\mathrm{AA}$ and BA samples. In fact, total diacids, oxoacids and $\alpha$ dicarbonyls were higher in non-irradiated AA than in BA. On the contrary, OC that contains several precursor compounds (including fatty acids) of diacids and related polar compounds is higher in BA than in AA (Table 1).

\subsection{Production and decomposition of short-chain diacids and related compounds}

A sharp increase was observed in the concentrations of $\omega \mathrm{C}_{2}$, $\omega \mathrm{C}_{4}$, Pyr, Gly and MeGly, but not $\omega \mathrm{C}_{3}$, with irradiation up to 18-24 h following a gradual decrease (Fig. 4), demonstrating an enhanced photochemical production of short-chain $\left(\leq \mathrm{C}_{4}\right)$ oxoacids and $\alpha$-dicarbonyls during an early stage of photochemical processing. It is likely because $\omega \mathrm{C}_{2}$, $\mathrm{Pyr}$, Gly and MeGly are produced by photochemical oxidation of aliphatic olefins and aromatic hydrocarbons and $\omega \mathrm{C}_{4}$ was produced from cyclic olefins and unsaturated fatty acids (Bandow et 


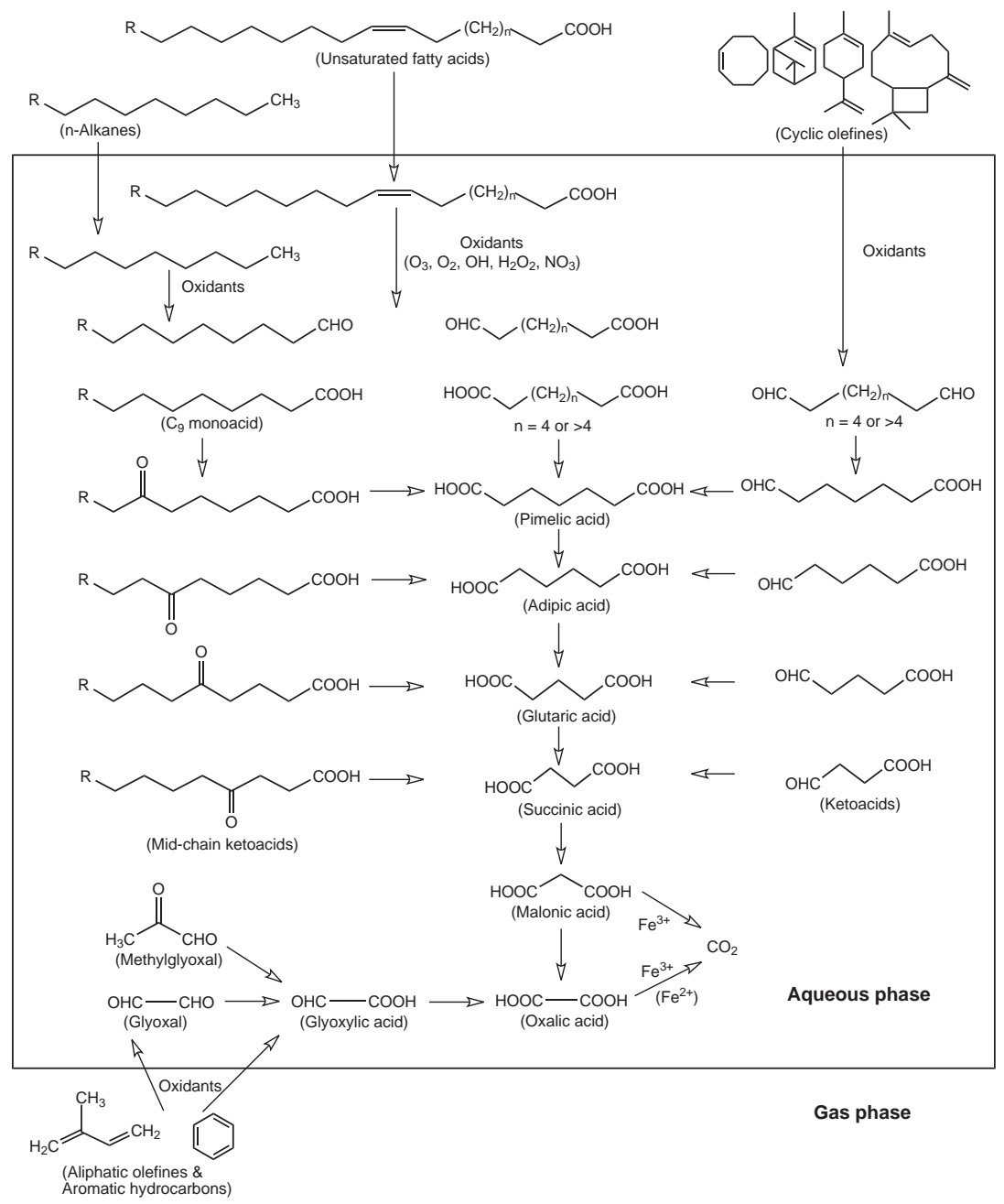

Figure 7. Possible photochemical formation and/or degradation pathways of diacids, oxoacids and $\alpha$-dicarbonyls in aqueous aerosols.

al., 1985; Hatakeyama et al., 1987; Kawamura et al., 1996a; Warneck, 2003; Lim et al., 2005), but $\omega \mathrm{C}_{3}$ may not be significantly produced from any of these precursor compounds (Fig. 7). The increasing trends of mass ratios of $\mathrm{C}_{2}$ to its precursor compounds, i.e., $\omega \mathrm{C}_{2}$, Pyr, Gly and MeGly as well as $\mathrm{C}_{3}$ (but not $\mathrm{C}_{4}$ ) diacid (Kawamura et al., 1996a; Warneck, 2003; Ervens et al., 2004b; Lim et al., 2005; Carlton et al., 2007), were found for BA near $120 \mathrm{~h}$ (Fig. 6a-e and f). It is noteworthy that $\mathrm{C}_{3} / \omega \mathrm{C}_{7}$ ratios also showed a slight increase, although they are not clear in the later stages of experiment (Fig. 6g), suggesting a potential formation of $\mathrm{C}_{3}$ diacid via $\omega \mathrm{C}_{7}$ that is derived from unsaturated fatty acids and/or cyclic olefins. In addition, $\mathrm{F} / \mathrm{M}$ ratios showed an increase with irradiation up to $48 \mathrm{~h}$ in AA and $18 \mathrm{~h}$ in BA followed by a gradual decrease until the end of experiment (Fig. 6i), indicating a significant photochemical transformation during an early stage of experiment and decomposition in a later stage.

Photochemical degradation of $\mathrm{C}_{2}$ and $\mathrm{C}_{3}$ diacids should have overwhelmed their photochemical production even in an early stage of the experiment except for a few cases (Fig. 3a, b). Diacids and other compounds containing a carbonyl group can form stable carboxylate salts with amines upon photochemical oxidation. However, based on laboratory studies, $\mathrm{C}_{2}$ and $\mathrm{C}_{3}$ diacids have been reported to decompose in aqueous phase in the presence of $\mathrm{Fe}^{3+}$ (and $\mathrm{C}_{2}$ diacid even in the presence of $\mathrm{Fe}^{2+}$ ) under UV irradiation at $254 \mathrm{~nm}$ as well as at a solar spectrum (> $300 \mathrm{~nm}$ ) (Zuo and Hoigne, 1994; Z. H. Wang et al., 2010; Pavuluri and Kawamura, 2012), but $\mathrm{C}_{2}$ diacid (and may be $\mathrm{C}_{3}$ diacid) is relatively stable in the absence of Fe species (Pavuluri and Kawamura, 2012). It is well documented that both $\mathrm{C}_{2}$ and $\mathrm{C}_{3}$ diacids have the strongest chelating capacity with $\mathrm{Fe}^{3+}$ among all diacids and tend to form mono, di- and trioxalato (equilibrium constant $\log _{10}(b)=9.4,16.2$ and 20.4 , respectively) and malonato (equilibrium constant $\log _{10}(\mathrm{~b})=7.5$, 13.3 and 16.9 , respectively) complexes by acting as ligands in aqueous phase, which exhibit a strong light-absorbing ability (Z. H. Wang et al., 2010). Although the equilibrium 
constant of $\mathrm{Fe}^{3+}$-malonato complex is slightly lower than that of $\mathrm{Fe}^{3+}$-oxalato, both diacids photolyze upon the absorption of UV light to result in $\mathrm{Fe}^{2+}$ and $\mathrm{CO}_{2}$ (Zuo and Hoigne, 1994; Z. H. Wang et al., 2010).

We found that non-irradiated $\mathrm{AA}$ and $\mathrm{BA}$ samples contain significant amounts of water-soluble $\mathrm{Fe}^{2+}$ and $\mathrm{Fe}^{3+}$ species (Table 1). Because a high abundance of particulate $\mathrm{Fe}$ is present in both AA and BA (Table 1), the concentrations of water-soluble $\mathrm{Fe}^{2+}$ and $\mathrm{Fe}^{3+}$ species in both $\mathrm{AA}$ and BA samples may increase upon UV irradiation; the waterinsoluble Fe can be transformed into water-soluble forms by photochemical processing of mineral aerosols (Solmon et al., 2009; Srinivas et al., 2012). However, we did not measure the concentrations of $\mathrm{Fe}^{2+}$ and $\mathrm{Fe}^{3+}$ species in the irradiated samples. In fact, the mass ratio of $\mathrm{C}_{2}$ diacid to $\mathrm{Fe}^{3+}$ is $15: 1$ in non-irradiated AA and 7:1 in BA, both of which are close to the ratio $(10: 1)$ used in laboratory experiments conducted by Pavuluri and Kawamura (2012) for Fe-catalyzed photolysis of $\mathrm{C}_{2}$ diacid in aqueous phase, in which the photolysis of $\mathrm{C}_{2}$ is very fast $\left(k=206 \mathrm{~L} \mathrm{~mol}^{-1} \mathrm{~s}^{-1}\right)$ and $99 \%$ of the $\mathrm{C}_{2}$ is degraded in $0.5 \mathrm{~h}$. Therefore, available water-soluble $\mathrm{Fe}^{3+}$ (and $\mathrm{Fe}^{2+}$ ) in AA and BA should be enough to promote the catalytic photochemical degradation of $\mathrm{C}_{2}$ (and $\mathrm{C}_{3}$ ) upon UV irradiation (Fig. 7) and thus the degradation rate of $\mathrm{C}_{2}$ (and $\mathrm{C}_{3}$ ) should have increased with the prolonged experiment due to enhancement in $\mathrm{Fe}^{3+}$ (and $\mathrm{Fe}^{2+}$ ) levels in the given sample.

The concentration of $\mathrm{C}_{2}$ diacid in AA decreased by $30 \%$ in $1.5 \mathrm{~h}$ and continued to decline by $90 \%$ until $12 \mathrm{~h}$ (Fig. 3a). However, the experiment of BA showed that the concentration of $\mathrm{C}_{2}$ decreased by 47 and $51 \%$ in 0.5 and $1.5 \mathrm{~h}$, respectively, and then gradually declined. The concentrations of $\mathrm{C}_{3}$ also showed similar trends with $\mathrm{C}_{2}$ (Fig. 3b). Although $\mathrm{C}_{2}$ and $\mathrm{C}_{3}$ diacids decreased sharply during early stages of experiment, they decreased gradually in the later stages despite possibly enhanced levels of water-soluble $\mathrm{Fe}^{2+}$ and $\mathrm{Fe}^{3+}$ species. These trends imply that photolysis of $\mathrm{C}_{2}$ and $\mathrm{C}_{3}$ diacids is highly significant in the presence of water-soluble $\mathrm{Fe}^{3+}$ (and $\mathrm{Fe}^{2+}$ ) (Fig. 7). However, the formation of both $\mathrm{C}_{2}$ and $\mathrm{C}_{3}$ diacids is also intensive with the photochemical processing of their precursor compounds in AA and BA. However, the net rate of production or degradation of $C_{2}$ and $C_{3}$ diacids in each experiment (Fig. 3a, b) should depend on the abundances of water-soluble $\mathrm{Fe}^{2+}$ and $\mathrm{Fe}^{3+}$ species and their precursors in AA and BA.

We found an increase in the mass ratios of MeGly to Gly with irradiation toward the end of the experiment, except for an early stage of the experiment (up to $6 \mathrm{~h}$ ) in AA, whereas in BA they remained relatively constant up to $36 \mathrm{~h}$ and then increased gradually up to $72 \mathrm{~h}$, followed by a rapid decrease (Fig. 6n). As noted earlier, concentrations of Gly and MeGly increased with experiment up to $18-24 \mathrm{~h}$ in both AA and BA. Thereafter, Gly decreased toward the end of experiment in both AA and BA, whereas MeGly remained relatively constant in the AA but decreased in BA (Fig. 4i, j). Such differ- ences should be caused by the difference in their production rates depending on the concentrations of potential precursors and their oxidation products in AA and BA, i.e., benzene and glycolaldehyde for Gly and acetone and higher alkanes $\left(>\mathrm{C}_{3}\right)$ and alkenes $\left(>\mathrm{C}_{2}\right)$ for MeGly (Fu et al., 2008), rather than the reaction rates of the Gly $\left(1.1 \times 10^{9} \mathrm{M}^{-1} \mathrm{~S}^{-1}\right)$ and MeGly $\left(6.44 \times 10^{8} \mathrm{M}^{-1} \mathrm{~S}^{-1}\right)$ with $\mathrm{HO}^{\bullet}$ in aqueous phase (Tan et al., 2012). Therefore, the higher abundance of MeGly than Gly in AA can be attributed to its enhanced production than the later species during photochemical processing of aqueous aerosols derived from anthropogenic sources. Furthermore, the oligomerization of Gly and MeGly (Tan et al., 2009, 2012; Lim et al., 2010) might have also played an important role on the changes in their concentrations with irradiation time; however, we did not focus on the measurements of oligomers here because of the analytical limitations.

\subsection{Possible photochemical pathways of long-chain diacids and oxoacids}

Enhanced concentrations of normal and branched $\mathrm{C}_{4}-\mathrm{C}_{7}$ diacids during an early stage (18-36h) (Fig. 3c-f), despite degradation of $\mathrm{C}_{2}$ and $\mathrm{C}_{3}$ and longer-chain $\left(>\mathrm{C}_{7}\right)$ diacids (Fig. 3a, b, g-k), may be caused by photochemical oxidation of the first-generation products derived from the oxidation of anthropogenic and/or biogenic VOCs (e.g., cycloalkenes, monoterpenes and sesquiterpenes) and unsaturated fatty acids (Kalberer et al., 2000; Gao et al., 2004) (Fig. 7). In addition, the photochemical oxidation of the polymers of polyunsaturated fatty acids, if available, can produce significant long-chain $\left(\geq \mathrm{C}_{4}\right)$ diacids (Harvey et al., 1983), a subject of future research. In fact, polyunsaturated fatty acids (e.g., linolenic acid, $\mathrm{C}_{18: 3}$ ) can undergo free radical oxidative cross-linking in the air and produce high-molecular-weight organic compounds (e.g., fulvic acid) (Wheeler, 1972; Harvey et al., 1983). Harvey et al. (1983) found a series of $\mathrm{C}_{4}-\mathrm{C}_{9}$ diacids by oxidizing the marine fulvic acid in a laboratory study. The chelating capability of succinate (equilibrium constant $\log _{10}(\mathrm{~b})=7.5 ; \mathrm{Z}$. H. Wang et al., 2010) and other long-chain diacids with $\mathrm{Fe}^{3+}$ is weak and, hence, their photolysis is insignificant. However, they should be further oxidized to result in lower diacids (Kawamura et al., 1996a; Matsunaga et al., 1999). The degradation of these diacids should be increased with increasing chain length because the oxidation rate of $\mathrm{C}_{4}$ to $\mathrm{C}_{9}$ diacids is increased with increasing carbon number (Yang et al., 2008a).

The relatively constant levels of $\mathrm{C}_{5}, i \mathrm{C}_{4}$ and $i \mathrm{C}_{5}$ during $36 \mathrm{~h}$ and $72-96 \mathrm{~h}$ (Fig. 3d, 1, m) may be due to the balance between photochemical production and degradation. The increases in the concentrations of $\mathrm{C}_{4}$ with a prolonged irradiation up to $72 \mathrm{~h}$ in BA and $96 \mathrm{~h}$ in AA further demonstrate its formation from higher diacids and other precursors in aqueous aerosols (Kawamura and Sakaguchi, 1999; Charbouillot et al., 2012) (Fig. 7). In fact, total diacids stayed relatively constant from $24 \mathrm{~h}$ to $72-96 \mathrm{~h}$ (Fig. $3 x$ ). In addi- 
tion, mass ratios of $\mathrm{C}_{4}$ to $\mathrm{C}_{5}-\mathrm{C}_{7}$ showed a gradual increase throughout the experiment (until $120 \mathrm{~h}$ ) in both AA and BA (Fig. 6k-m). These results support a photochemical breakdown of longer-chain $\left(\geq \mathrm{C}_{5}\right.$ ) diacids resulting in $\mathrm{C}_{4}$ (Matsunaga et al., 1999; Yang et al., 2008a; Charbouillot et al., 2012). Yang et al. (2008a) reported that the production of $\mathrm{C}_{4}$ diacid is predominant, followed by $\mathrm{C}_{5}$ diacid during a laboratory photochemical oxidation of $\mathrm{C}_{6}-\mathrm{C}_{9}$ diacids.

In addition, $\omega \mathrm{C}_{8}$ acid, which can be produced by the oxidation of cyclic olefins and unsaturated fatty acids (Kawamura and Sakaguchi, 1999; Gao et al., 2004), showed a gradual increase (Fig. 4e) similar to that of $\mathrm{C}_{4}$ diacid (Fig. 3c) in both $\mathrm{AA}$ and $\mathrm{BA}$, suggesting a significant photochemical production of $\mathrm{C}_{4}$ via $\omega \mathrm{C}_{8}$ until the consumption of the precursor compounds derived from anthropogenic and biogenic VOCs and biogenic unsaturated fatty acids (Kalberer et al., 2000; Gao et al., 2004). In fact, ratios of $\mathrm{C}_{4}$ to $\mathrm{C}_{5}-$ $\mathrm{C}_{7}$ were 10 times higher in BA than in AA whereas those of $\mathrm{C}_{4} / \omega \mathrm{C}_{8}$ were similar in both the BA and AA (Fig. 6j). However, their temporal profiles with irradiation time are similar in both $\mathrm{AA}$ and $\mathrm{BA}$. These results suggest that the formation of $\mathrm{C}_{4}$ and $\omega \mathrm{C}_{8}$ is much higher in biogenic aerosols than in anthropogenic aerosols compared to $\mathrm{C}_{5}-\mathrm{C}_{7}$ diacids, but their formation/degradation processes may be similar irrespective of the origin of precursors. However, it is not clear from this study whether $\mathrm{C}_{4}$ is mainly derived (via $\omega \mathrm{C}_{8}$ ) from cyclic olefins or unsaturated fatty acids (Fig. 7).

It is well established that long-chain $\left(\mathrm{C}_{8}-\mathrm{C}_{12}\right)$ diacids are formed by photochemical oxidation of unsaturated fatty acids (e.g., oleic acid) (Kawamura and Gagosian, 1987; Matsunaga et al., 1999) (Fig. 7). However, unsaturated fatty acids were not abundant (e.g., oleic acid was $0.89 \mathrm{ng} \mathrm{m}^{-3}$ in AA and below detection limit in BA) in non-irradiated samples (Fu et al., 2010). Hence, photochemical formation of longchain diacids from the oxidation of unsaturated fatty acids should be less important during the experiment, although chemical forms of polymerized and/or partially oxidized unsaturated fatty acids may be abundant in the aerosols. The rate constant of photooxidation of diacids increases with an increase in carbon number of individual diacids $\left(\geq \mathrm{C}_{4}\right.$ ) (Yang et al., 2008a). Hence, photochemical breakdown of $\mathrm{C}_{8}-\mathrm{C}_{12}$ diacids to lower diacids (Matsunaga et al., 1999; Yang et al., 2008a) should be very likely (Fig. 7). The gradual decreases of aliphatic unsaturated diacids, aromatic diacids and oxoacids, except for $\omega \mathrm{C}_{8}$, with irradiation are likely caused by the photochemical degradation (Fig. 7).

\subsection{Atmospheric implications}

As discussed above, this study reveals that photochemical degradation of $\mathrm{C}_{2}$ and $\mathrm{C}_{3}$ (due to Fe-catalyzed photolysis) in aqueous aerosols overwhelmed their production whereas $\mathrm{C}_{4}$ diacid showed photochemical formation. These results are consistent with the recent atmospheric observations: a significant reduction in $\mathrm{C}_{2}$ diacid concentration and an inverse re- lationship between the $\mathrm{C}_{2}$ and $\mathrm{Fe}$ in cloud water (Sorooshian et al., 2013) and the replacement of the predominance of $\mathrm{C}_{2}$ by $\mathrm{C}_{4}$ in the Arctic aerosols (Kawamura et al., 2010, 2012). It was also reported that $\mathrm{C}_{4}$ and $\mathrm{C}_{5}$ diacids are most abundant among $\mathrm{C}_{3}-\mathrm{C}_{8}$ diacids determined during the photochemical oxidation of $\mathrm{C}_{6}-\mathrm{C}_{9}$ diacids in a laboratory experiment (Yang et al., 2008a).

On the contrary, the enhanced degradation of $\mathrm{C}_{2}$ and $\mathrm{C}_{3}$ and the formation of $\mathrm{C}_{4}$ diacid upon prolonged irradiation are not consistent with previous laboratory, observation and model studies on photochemical production and degradation of diacids and related compounds in aqueous phase (e.g., cloud processing) (Kawamura et al., 1996a; Kawamura and Sakaguchi, 1999; Warneck, 2003; Ervens et al., 2004b; Lim et al., 2005; Carlton et al., 2007; Charbouillot et al., 2012). In fact, previous studies did not consider Fe-catalyzed photolysis of $\mathrm{C}_{2}$ diacid, which is significant at least in Fe-rich atmospheric waters. However, the formation processes and potential precursor compounds of $\mathrm{C}_{4}$ diacid have not been fully explored yet. Moreover, previous laboratory experiments on aqueous solutions of specific species did not consider the mixing state of organic and inorganic constituents in atmospheric aerosols (Ervens et al., 2011), although simplified experiments sometimes provide useful information on mechanisms.

Generally, it has been considered that the anthropogenic contributions of $\alpha$-dicarbonyls to organic aerosols are minor: $8 \%$ for Gly and $5 \%$ for MeGly (Fu et al., 2008). To the best of our knowledge, their production in atmospheric waters has not been well recognized yet. Our laboratory experiments indicate that the photochemical production of Gly and MeGly is significant in aqueous aerosols. The production of MeGly is more pronounced compared to Gly with prolonged photochemical processing of aqueous anthropogenic aerosols. Finally, our findings based on the batch laboratory experiment emphasize the importance of the photolysis of $\mathrm{C}_{2}$ and $\mathrm{C}_{3}$ diacids and photochemical production of $\mathrm{C}_{4}$ diacid and $\alpha$ dicarbonyls in aqueous aerosols to reconcile the current atmospheric model(s) such as the cloud parcel model (Ervens et al., 2004a) and to better understand the secondary organic aerosol budget and its climatic impacts.

\section{Summary and conclusions}

In this study, we conducted batch UV irradiation experiments on AA and BA aerosol samples collected from Chennai, India, in the presence of moisture for the reaction time of 0.5 to $120 \mathrm{~h}$. The irradiated samples were analyzed for molecular compositions of diacids, oxoacids and $\alpha$-dicarbonyls. Concentrations of $\mathrm{C}_{2}$ and $\mathrm{C}_{3}$ and $\mathrm{C}_{8}-\mathrm{C}_{12}$ diacids decreased with an increase in reaction time of $12-24 \mathrm{~h}$. In contrast, $\mathrm{C}_{4}$ diacid (and $\mathrm{C}_{5}-\mathrm{C}_{7}$ ) showed a significant increase with reaction time up to $72 \mathrm{~h}$ in BA and $96 \mathrm{~h}$ in AA. Oxoacids and $\alpha$-dicarbonyls showed a significant increase during an early stage of irradi- 
ation followed by a gradual decrease in the prolonged experiment with the exception of $\omega \mathrm{C}_{8}$ acid, which showed a pattern similar to $\mathrm{C}_{4}$ diacid, and methylglyoxal, which remained relatively abundant from $24 \mathrm{~h}$ to the end of the experiment in AA. The mass ratios of $\mathrm{C}_{2}$ diacid to its precursors, i.e., glyoxylic acid, pyruvic acid, $\alpha$-dicarbonyls (glyoxal and methylglyoxal) and $\mathrm{C}_{3}$, showed a considerable increase with irradiation, while those of $\mathrm{C}_{4}$ to $\mathrm{C}_{5}-\mathrm{C}_{7}$ diacids and $\omega \mathrm{C}_{8}$ acid and methylglyoxal to glyoxal in AA showed a significant increase with irradiation. These results demonstrate that degradation of $\mathrm{C}_{2}$ and $\mathrm{C}_{3}$ (and $\mathrm{C}_{8}-\mathrm{C}_{12}$ ) and formation of $\mathrm{C}_{4}$ (and $\mathrm{C}_{5}-\mathrm{C}_{7}$ ) are enhanced with photochemical processing of aqueous aerosols. This study further infers that ironcatalyzed photolysis of $\mathrm{C}_{2}$ and $\mathrm{C}_{3}$ diacids and photochemical formation of $\mathrm{C}_{4}$ diacid via $\omega \mathrm{C}_{8}$ acid derived from cyclic olefins and/or unsaturated fatty acids play an important role in controlling their abundances in the atmosphere with photochemical processing of aqueous aerosols. This study also suggests that photochemical production of $\alpha$-dicarbonyls, in particular methylglyoxal, in anthropogenic aerosols is significant.

Acknowledgements. This study was in part supported by the Japan Society for the Promotion of Science (JSPS) (grant-in-aid nos. 19204055 and 24221001). C. M. Pavuluri appreciates the financial support from JSPS Fellowship. The authors appreciate the helpful comments of two anonymous reviewers.

Edited by: M. Ammann

\section{References}

Albrecht, B. A.: Aerosols, Cloud Microphysics, and Fractional Cloudiness, Science, 245, 1227-1230, 1989.

Arakaki, T. and Faust, B. C.: Sources, Sinks, and Mechanisms of Hydroxyl Radical (Oh) Photoproduction and Consumption in Authentic Acidic Continental Cloud Waters from Whiteface Mountain, New York: The Role of the $\mathrm{Fe}(\mathrm{R})(\mathrm{R}=\mathrm{Ii}, \mathrm{III})$ Photochemical Cycle, J. Geophys. Res.-Atmos., 103, 3487-3504, 1998.

Bandow, H., Washida, N., and Akimoto, H.: Ring-Cleavage Reactions of Aromatic-Hydrocarbons Studied by Ft-Ir Spectroscopy .1. Photooxidation of Toluene and Benzene in the Nox-Air System, B. Chem. Soc. Jpn., 58, 2531-2540, 1985.

Carlton, A. G., Turpin, B. J., Lim, H. J., Altieri, K. E., and Seitzinger, S.: Link between Isoprene and Secondary Organic Aerosol (Soa): Pyruvic Acid Oxidation Yields Low Volatility Organic Acids in Clouds, Geophys. Res. Lett., 33, L06822, doi:10.1029/2005GL025374, 2006.

Carlton, A. G., Turpin, B. J., Altieri, K. E., Seitzinger, S., Reff, A., Lim, H. J., and Ervens, B.: Atmospheric Oxalic Acid and Soa Production from Glyoxal: Results of Aqueous Photooxidation Experiments, Atmos. Environ., 41, 7588-7602, 2007.

Charbouillot, T., Gorini, S., Voyard, G., Parazols, M., Brigante, M., Deguillaume, L., Delort, A. M., and Mailhot, G.: Mechanism of
Carboxylic Acid Photooxidation in Atmospheric Aqueous Phase: Formation, Fate and Reactivity, Atmos. Environ., 56, 1-8, 2012. Chebbi, A. and Carlier, P.: Carboxylic Acids in the Troposphere, Occurrence, Sources, and Sinks: A Review, Atmos. Environ., 30, 4233-4249, 1996.

Chitose, N., Ueta, S., Seino, S., and Yamamoto, T. A.: Radiolysis of Aqueous Phenol Solutions with Nanoparticles. 1. Phenol Degradation and Toc Removal in Solutions Containing Tio2 Induced by Uv, Gamma-Ray and Electron Beams, Chemosphere, 50, 1007-1013, 2003.

Ervens, B., Feingold, G., Clegg, S. L., and Kreidenweis, S. M.: A Modeling Study of Aqueous Production of Dicarboxylic Acids: 2. Implications for Cloud Microphysics, J. Geophys. Res.Atmos., 109, D15206, doi:10.1029/2004JD004575, 2004a.

Ervens, B., Feingold, G., Frost, G. J., and Kreidenweis, S. M.: A Modeling Study of Aqueous Production of Dicarboxylic Acids: 1. Chemical Pathways and Speciated Organic Mass Production, J. Geophys. Res.-Atmos., 109, D15205, doi:10.1029/2003jd004387, 2004b.

Ervens, B., Turpin, B. J., and Weber, R. J.: Secondary organic aerosol formation in cloud droplets and aqueous particles (aqSOA): a review of laboratory, field and model studies, Atmos. Chem. Phys., 11, 11069-11102, doi:10.5194/acp-1111069-2011, 2011.

Fu, P. Q., Kawamura, K., Pavuluri, C. M., Swaminathan, T., and Chen, J.: Molecular characterization of urban organic aerosol in tropical India: contributions of primary emissions and secondary photooxidation, Atmos. Chem. Phys., 10, 2663-2689, doi:10.5194/acp-10-2663-2010, 2010.

Fu, T. M., Jacob, D. J., Wittrock, F., Burrows, J. P., Vrekoussis, M., and Henze, D. K.: Global Budgets of Atmospheric Glyoxal and Methylglyoxal, and Implications for Formation of Secondary Organic Aerosols, J. Geophys. Res.-Atmos., 113, D15303, doi:10.1029/2007JD009505, 2008.

Gao, S., Keywood, M., Ng, N. L., Surratt, J., Varutbangkul, V., Bahreini, R., Flagan, R. C., and Seinfeld, J. H.: Low-MolecularWeight and Oligomeric Components in Secondary Organic Aerosol from the Ozonolysis of Cycloalkenes and A-Pinene, J. Phys. Chem. A, 108, 10147-10164, 2004.

Garg, A., Bhattacharya, S., Shukla, P. R., and Dadhwal, W. K.: Regional and Sectoral Assessment of Greenhouse Gas Emissions in India, Atmos. Environ., 35, 2679-2695, 2001.

Giebl, H., Berner, A., Reischl, G., Puxbaum, H., Kasper-Giebl, A., and Hitzenberger, R.: Ccn Activation of Oxalic and Malonic Acid Test Aerosols with the University of Vienna Cloud Condensation Nuclei Counter, J. Aerosol. Sci., 33, 1623-1634, 2002.

Harvey, G. R., Boran, D. A., Chesal, L. A., and Tokar, J. M.: The Structure of Marine Fulvic and Humic Acids, Mar. Chem., 12, 119-132, 1983.

Hatakeyama, S., Ohno, M., Weng, J. H., Takagi, H., and Akimoto, H.: Mechanism for the Formation of Gaseous and Particulate Products from Ozone-Cycloalkene Reactions in Air, Environ. Sci. Technol., 21, 52-57, 1987.

Kalberer, M., Yu, J., Cocker, D. R., Flagan, R. C., and Seinfeld, J. H.: Aerosol Formation in the Cyclohexene-Ozone System, Environ. Sci. Technol., 34, 4894-4901, 2000.

Kanakidou, M., Seinfeld, J. H., Pandis, S. N., Barnes, I., Dentener, F. J., Facchini, M. C., Van Dingenen, R., Ervens, B., Nenes, A., Nielsen, C. J., Swietlicki, E., Putaud, J. P., Balkanski, Y., Fuzzi, 
S., Horth, J., Moortgat, G. K., Winterhalter, R., Myhre, C. E. L., Tsigaridis, K., Vignati, E., Stephanou, E. G., and Wilson, J.: Organic aerosol and global climate modelling: a review, Atmos. Chem. Phys., 5, 1053-1123, doi:10.5194/acp-5-1053-2005, 2005.

Kawamura, K.: Identification of $\mathrm{C}_{2}-\mathrm{C}_{10} \Omega$-Oxocarboxylic Acids, Pyruvic Acid, and $\mathrm{C}_{2}-\mathrm{C}_{3}$ A-Dicarbonyls in Wet Precipitation and Aerosol Samples by Capillary Gc and Gc / Ms, Anal. Chem., 65, 3505-3511, 1993.

Kawamura, K. and Gagosian, R. B.: Implications of $\Omega$ Oxocarboxylic Acids in the Remote Marine Atmosphere for Photooxidation of Unsaturated Fatty Acids, Nature, 325, 330-332, 1987.

Kawamura, K. and Ikushima, K.: Seasonal Changes in the Distribution of Dicarboxylic Acids in the Urban Atmosphere, Environ. Sci. Technol., 27, 2227-2235, 1993.

Kawamura, K. and Kaplan, I. R.: Motor Exhaust Emissions as a Primary Source for Dicarboxylic-Acids in Los-Angeles Ambient Air, Environ. Sci. Technol., 21, 105-110, 1987.

Kawamura, K. and Sakaguchi, F.: Molecular Distributions of Water Soluble Dicarboxylic Acids in Marine Aerosols over the Pacific Ocean Including Tropics, J. Geophys. Res.-Atmos., 104, 35013509, 1999.

Kawamura, K., Kasukabe, H., and Barrie, L. A.: Source and Reaction Pathways of Dicarboxylic Acids, Ketoacids and Dicarbonyls in Arctic Aerosols: One Year of Observations, Atmos. Environ., 30, 1709-1722, 1996a.

Kawamura, K., Sempéré, R., Imai, Y., Fujii, Y., and Hayashi, M.: Water Soluble Dicarboxylic Acids and Related Compounds in Antarctic Aerosols, J. Geophys. Res.-Atmos., 101, 1872118728, $1996 \mathrm{~b}$.

Kawamura, K., Yokoyama, K., Fujii, Y., and Watanabe, O.: A Greenland Ice Core Record of Low Molecular Weight Dicarboxylic Acids, Ketocarboxylic Acids, and Alpha-Dicarbonyls: A Trend from Little Ice Age to the Present (1540 to 1989 Ad), J. Geophys. Res.-Atmos., 106, 1331-1345, 2001.

Kawamura, K., Kasukabe, H., and Barrie, L. A.: Secondary Formation of Water-Soluble Organic Acids and A-Dicarbonyls and Their Contributions to Total Carbon and Water-Soluble Organic Carbon: Photochemical Aging of Organic Aerosols in the Arctic Spring, J. Geophys. Res.-Atmos., 115, D21306 doi:10.1029/2010JD014299, 2010.

Kawamura, K., Ono, K., Tachibana, E., Charriére, B., and Sempéré, R.: Distributions of low molecular weight dicarboxylic acids, ketoacids and a-dicarbonyls in the marine aerosols collected over the Arctic Ocean during late summer, Biogeosciences, 9, 47254737, doi:10.5194/bg-9-4725-2012, 2012.

Lelieveld, J., Crutzen, P. J., Ramanathan, V., Andreae, M. O., Brenninkmeijer, C. A. M., Campos, T., Cass, G. R., Dickerson, R. R., Fischer, H., de Gouw, J. A., Hansel, A., Jefferson, A., Kley, D., de Laat, A. T. J., Lal, S., Lawrence, M. G., Lobert, J. M., Mayol-Bracero, O. L., Mitra, A. P., Novakov, T., Oltmans, S. J., Prather, K. A., Reiner, T., Rodhe, H., Scheeren, H. A., Sikka, D., and Williams, J.: The Indian Ocean Experiment: Widespread Air Pollution from South and Southeast Asia, Science, 291, 10311036, 2001.

Lim, H. J., Carlton, A. G., and Turpin, B. J.: Isoprene Forms Secondary Organic Aerosol through Cloud Processing: Model Simulations, Environ. Sci. Technol., 39, 4441-4446, 2005.
Lim, Y. B., Tan, Y., Perri, M. J., Seitzinger, S. P., and Turpin, B. J.: Aqueous chemistry and its role in secondary organic aerosol (SOA) formation, Atmos. Chem. Phys., 10, 1052110539, doi:10.5194/acp-10-10521-2010, 2010.

Mahowald, N., Jickells, T. D., Baker, A. R., Artaxo, P., BenitezNelson, C. R., Bergametti, G., Bond, T. C., Chen, Y., Cohen, D. D., Herut, B., Kubilay, N., Losno, R., Luo, C., Maenhaut, W., McGee, K. A., Okin, G. S., Siefert, R. L., and Tsukuda, S.: Global Distribution of Atmospheric Phosphorus Sources, Concentrations, and Deposition Rates, and Anthropogenic Impacts, Global Biogeochem. Cy., 22, GB4026, doi:10.1029/2008GB003240, 2008.

Matsunaga, S., Kawamura, K., Nakatsuka, T., and Ohkouchi, N.: Preliminary Study on Laboratory Photochemical Formation of Low Molecular Weight Dicarboxylic Acids from Unsaturated Fatty Acid (Oleic Acid), Res. Org. Geochem., 14, 19-25, 1999.

Narukawa, M., Kawamura, K., Takeuchi, N., and Nakajima, T.: Distribution of Dicarboxylic Acids and Carbon Isotopic Compositions in Aerosols from 1997 Indonesian Forest Fires, Geophys. Res. Lett., 26, 3101-3104, 1999.

Nozière, B., Ekstrom, S., Alsberg, T., and Holmstrom, S.: Radical-Initiated Formation of Organosulfates and Surfactants in Atmospheric Aerosols, Geophys. Res. Lett., 37, L05806, doi:10.1029/2009GL041683, 2010.

Pacyna, J. M. and Pacyna, E. G.: An Assessment of Global and Regional Emissions of Trace Metals to the Atmosphere from Anthropogenic Sources Worldwide, Environ. Rev., 9, 269-298, 2001.

Padhy, P. K. and Varshney, C. K.: Emission of Volatile Organic Compounds (Voc) from Tropical Plant Species in India, Chemosphere, 59, 1643-1653, 2005.

Pavuluri, C. M. and Kawamura, K.: Evidence for 13-Carbon Enrichment in Oxalic Acid Via Iron Catalyzed Photolysis in Aqueous Phase, Geophys. Res. Lett., 39, L03802, doi:10.1029/2011GL050398, 2012.

Pavuluri, C. M., Kawamura, K., and Swaminathan, T.: WaterSoluble Organic Carbon, Dicarboxylic Acids, Ketoacids, and Alpha-Dicarbonyls in the Tropical Indian Aerosols, J. Geophys. Res.-Atmos., 115, D11302, doi:10.1029/2009jd012661, 2010.

Pavuluri, C. M., Kawamura, K., Aggarwal, S. G., and Swaminathan, T.: Characteristics, seasonality and sources of carbonaceous and ionic components in the tropical aerosols from Indian region, Atmos. Chem. Phys., 11, 8215-8230, doi:10.5194/acp-11-82152011, 2011.

Reddy, M. S. and Venkataraman, C.: Inventory of Aerosol and Sulphur Dioxide Emissions from India: I - Fossil Fuel Combustion, Atmos. Environ., 36, 677-697, 2002a.

Reddy, M. S. and Venkataraman, C.: Inventory of Aerosol and Sulphur Dioxide Emissions from India. Part II - Biomass Combustion, Atmos. Environ., 36, 699-712, 2002b.

Saxena, P. and Hildemann, L. M.: Water-Soluble Organics in Atmospheric Particles: A Critical Review of the Literature and Application of Thermodynamics to Identify Candidate Compounds, J. Atmos. Chem., 24, 57-109, 1996.

Shirayama, H., Tohezo, Y., and Taguchi, S.: Photodegradation of Chlorinated Hydrocarbons in the Presence and Absence of Dissolved Oxygen in Water, Water Res., 35, 1941-1950, 2001.

Solmon, F., Chuang, P. Y., Meskhidze, N., and Chen, Y.: Acidic Processing of Mineral Dust Iron by Anthropogenic Compounds over 
the North Pacific Ocean, J. Geophys. Res.-Atmos., 114, D02305, doi:10.1029/2008JD010417, 2009.

Sorooshian, A., Wang, Z., Coggon, M. M., Jonsson, H. H., and Ervens, B.: Observations of Sharp Oxalate Reductions in Stratocumulus Clouds at Variable Altitudes: Organic Acid and Metal Measurements During the 2011 E-Peace Campaign, Environ. Sci. Technol., 47, 7747-7756, 2013.

Srinivas, B., Sarin, M. M., and Kumar, A.: Impact of Anthropogenic Sources on Aerosol Iron Solubility over the Bay of Bengal and the Arabian Sea, Biogeochemistry, 110, 257-268, 2012.

Stookey, L. C.: Ferrozine - a New Spectrophotometric Reagent for Iron, Anal. Chem., 42, 779-781, 1970.

Tan, Y., Perri, M. J., Seitzinger, S. P., and Turpin, B. J.: Effects of Precursor Concentration and Acidic Sulfate in Aqueous GlyoxalOh Radical Oxidation and Implications for Secondary Organic Aerosol, Environ. Sci. Technol., 43, 8105-8112, 2009.

Tan, Y., Lim, Y. B., Altieri, K. E., Seitzinger, S. P., and Turpin, B. J.: Mechanisms leading to oligomers and SOA through aqueous photooxidation: insights from $\mathrm{OH}$ radical oxidation of acetic acid and methylglyoxal, Atmos. Chem. Phys., 12, 801-813, doi:10.5194/acp-12-801-2012, 2012.

Theodosi, C., Markaki, Z., and Mihalopoulos, N.: Iron Speciation, Solubility and Temporal Variability in Wet and Dry Deposition in the Eastern Mediterranean, Mar. Chem., 120, 100-107, 2010a.

Theodosi, C., Markaki, Z., Tselepides, A., and Mihalopoulos, N.: The Significance of Atmospheric Inputs of Soluble and Particulate Major and Trace Metals to the Eastern Mediterranean Seawater, Mar. Chem., 120, 154-163, 2010 b.

Tilgner, A. and Herrmann, H.: Radical-Driven Carbonyl-to-Acid Conversion and Acid Degradation in Tropospheric Aqueous Systems Studied by Capram, Atmos. Environ., 44, 5415-5422, 2010.
Twomey, S.: Influence of Pollution on Shortwave Albedo of Clouds, J. Atmos. Sci., 34, 1149-1152, 1977.

Wang, G., Xie, M., Hu, S., Gao, S., Tachibana, E., and Kawamura, K.: Dicarboxylic acids, metals and isotopic compositions of $\mathrm{C}$ and $\mathrm{N}$ in atmospheric aerosols from inland China: implications for dust and coal burning emission and secondary aerosol formation, Atmos. Chem. Phys., 10, 6087-6096, doi:10.5194/acp-106087-2010, 2010.

Wang, Z. H., Chen, X., Ji, H. W., Ma, W. H., Chen, C. C., and Zhao, J. C.: Photochemical Cycling of Iron Mediated by Dicarboxylates: Special Effect of Malonate, Environ. Sci. Technol., 44, 263-268, 2010.

Warneck, P.: In-Cloud Chemistry Opens Pathway to the Formation of Oxalic Acid in the Marine Atmosphere, Atmos. Environ., 37, 2423-2427, 2003.

Weeks, J. L., Meaburn, G. M., and Gordon, S.: Absorption Coefficients of Liquid Water and Aqueous Solutions in the Far Ultraviolet, Radiat. Res., 19, 559-567, 1963.

Wheeler, J.: Some Effects of Solar Levels of Ultraviolet-Radiation on Lipids in Artificial Sea-Water, J. Geophys. Res., 77, 53025306, 1972.

Yang, L. M., Ray, M. B., and Yu, L. E.: Photooxidation of Dicarboxylic Acids- Part Ii: Kinetics, Intermediates and Field Observations, Atmos. Environ., 42, 868-880, 2008a.

Yang, L. M., Ray, M. B., and Yu, L. E.: Photooxidation of Dicarboxylic Acids- Part 1: Effects of Inorganic Ions on Degradation of Azelaic Acid, Atmos. Environ., 42, 856-867, $2008 \mathrm{~b}$.

Zuo, Y. G. and Hoigne, J.: Photochemical Decomposition of Oxalic, Glyoxalic and Pyruvic Acid Catalyzed by Iron in Atmospheric Waters, Atmos. Environ., 28, 1231-1239, 1994. 